\title{
NEGOTIATION OF SCIENTIFIC DISCOURSE IN THE FIRST PRINTED EDITION OF THE HISTORIA DE LA DONZELLA TEODOR (TOLEDO: PEDRO HAGENBACH, CA. 1500)
}

\author{
ISIDRO J. RIVERA \\ University of Kansas
}

Para Rosarito

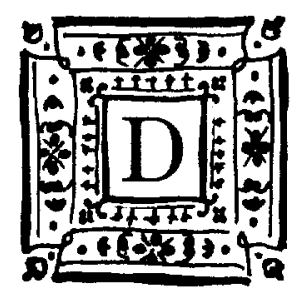

ESPITE its popularity in the literature of the late Middle Ages, the Historia de la donzella Teodor has remained outside the conventional canon of medieval European literature. ${ }^{1}$ The story of the young slave girl named Teodor belongs to the didactic writings associated with medieval sapiential literature collections (Deyermond 183; Haro Cortés, Los compendios 41-45). Parker has recently noted that the survival of the text was due in part to the text's affiliation with "the wisdom literature category" (120). The text is frequently found as one of the appendices to the Bocados de oro, a Castilian translation of Mukhtâr al hikam, an Arabic didactic text which circulated in several vernacular versions. ${ }^{2}$ The manuscript tradition of the Historia de la

\footnotetext{
${ }^{1}$ Baranda and Infantes (70-74) have identified twelve printings of the work between 1500 and 1554. Only one other pre-1400 text, the Crónica troyana with thirteen editions, surpasses the number of reprintings of the Historia de la donzella Teodor during the period under study (Simón Díaz 382). By comparison, one of the most widely disseminated Castilian texts in the medieval period, the Bocados de oro, was reprinted only six times (Simón Díaz 382).

${ }^{2}$ Version $\mathrm{C}$ of the Bocados de oro contains the Historia de la donzella Teodor. Witnesses to this tradition exist in Escorial Ms. h.II.6, BNM Ms. 17822, BNM Ms. 17853,
} 
ical sciences, folk traditions, medicine, and social practices. Throughout the questioning by the court scholars, Teodor's erudition provides the readers with concrete information on a variety of subjects:

E dixo el fisico quales son las frutas \& dixo la donzella para los dolientes las mançanas \& las almendra[s] \& otorgo conella el fisyco \& pregunto dela sangrya \& dyxo la donzella la sangria es buena martes \& luna menguante \& el çielo esconbrado de nubes \& sera el cuerpo espaçioso \& alegre el figado. (Escorial, Ms. h-III-6, folio 120r)

E rrespondio \& dixole lo que es mas pesado que los mo〈n〉tes es el agua \& mass apresurado que la saeta el ojo \& mas aguda q〈ue la espada la lengua $\&$ mas ardiente que el fuego es coraçon \& mas dulçe que la miel el buen fijo $\&$ dolençia syn melezina es la locura. (Escorial, Ms. h-III-6, folios. 122v$123 \mathrm{r})^{4}$

The question/answer structure provides a vehicle for imparting a wide range of information in a concise format. At the same time the presentation engages the readers' interest in the outcome of the story and the triumph of Teodor's knowledge.

With the advent of print, the medieval tale underwent some significant modifications in content. The earliest extant printed edition of the Historia de la donzella Teodor, published in Toledo by Pedro Hagenbach around 1500-1503, incorporates material not found in the extant manuscript tradition. The sole witness of the Toledo edition survives in an imperfect copy housed in the Biblioteca de Catalunya, Barcelona, with the shelfmark Inc. $7 .{ }^{5}$ Hagenbach's text contains two significant additions: a popular hygienic calendar providing recommendations for each of the months of the year and a series of recommendations concerning human sexology. Both these textual additions move the Historia de la donzella Teodor into the area of popular scientific writing and reflect the emergence in late medieval Castile of a readership which preferred utilitarian works (Nalle 92).

During the late fifteenth century, new practices had begun to exert a profound influence on the production and reception of printed

${ }^{4}$ I utilize the transcription of the Escorial manuscript made by Donna Rogers. Subsequent citations from the El Escorial Ms. h-III- 6 will be from the transcription by Rogers.

"All citations from the Historia de la donzella Teodor are taken from the Toledo incunable. In general, I have respected the orthography of that edition and have not added accents or modem punctuation. All abbreviations have been silently expanded. I have used " $e$ " to transcribe the tironian sign. In preparing this essay, I have consulted Mettmann's edition. 
books. The variable nature of the publishing industry during the first decades of the press required publishers to adapt production in response to changes within the marketplace. Goldschmidt reminds us: "Printing was from the start a commercial enterprise, and however often printers and publishers have lost their money in the past five centuries, there has never been a book that went to press unless the printer rightly or wrongly believed he could make a profit by printing it" (13). Publishers in the Iberian Peninsula as well as throughout Europe were responding to numerous changes in the marketplace and in their readership (Chambers; Rivera). The production of books increasingly became dependent on the needs of the readership and on the economic forces affecting the market. In Castile during this crucial period, readers seemed to be inclined to own books which imparted practical knowledge and information (Lawrance 90). Nalle's research (92) has confirmed this predilection for utilitarian works and for books which would contribute to the improvement of the reader's life. While devotional, moralizing, and historical works accounted for much of the book production in the first century of the press, Whinnom stresses the prevalence in early modern Castile of a literature which "provides guidance for the individual to adjust to the world and the society around him" (170).

According to Chambers, by the late fifteenth century publishers in Castile had already begun to tailor their production to books of a popular nature (12). Publishers shifted their activities toward vernacular books which would target a larger reading public. Imprints of chivalric tales, compendia of saints' lives, imaginative fiction, guidebooks, and story collections began to dominate book production. Hagenbach was no exception to this phenomenon. His press was active in Toledo from 1498 until 1503 when the shop passed to an anonymous successor (Norton 366). In addition to religious and devotional works, his output included important editions of representative popular works from the late fifteenth century: the Comedia de Calisto y Melibea (Toledo, 1500), Cárcel de Amor (Toledo, 1500), Historia del emperador Carlos Magno (Toledo, 1500-1503). In addition, Hagenbach was quite familiar with the wisdom literature tradition circulating during the late fifteenth century. His press had published an edition of Bocados in 1502 (Norton n. 1025) Significantly, that edition reproduces the Version B branch of Bocados in which the Historia de la donzella Teodor does not figure. 
It is reasonable to assume that the output of Hagenbach's press sought to address the preferences of his prospective consumers. In the case of the Historia de la donzella Teodor, the printed edition attests to a series of negotiations by Hagenbach which resulted in a text significantly different from the one circulating in manuscript form during the fourteenth and fifteenth centuries. The decision by Hagenbach to print this text transformed the medieval tale of the young slave girl Teodor into a "popular text" capable of satisfying the interests of early modern readers.

Research on the Historia de la donzella Teodor has overlooked the publisher's role in producing and negotiating texts in response to changes in readership. Cynthia Brown, in an important study of the relationships between printers and authors during the first century of printing, has noted that a text acquires identity through the active involvement of a publisher who, recognizing the market potential of a work, decides to oversee the production of a book (62). Roger Chartier has suggested that publishers often created books as a response to what they perceived as the wishes of their readership (13). In some cases, publishers created new identities for texts by altering or refashioning the original work in order to suit individual needs (Brown 61-62).

The activity of Hagenbach's press reflects the historical reality of book production in Castile during the first century after the invention of the press. Evidence from the first printed edition of the Historia de la donzella Teodor shows that Hagenbach had undertaken a distinctive refashioning of the original text. The size and format of the edition ( $166 \times 98 \mathrm{~mm}$ without columns) and the use of gothic typeface fit the pattern of vernacular books printed for non-specialist readers. ${ }^{6}$ At the same time, Hagenbach, aware of the realities of publishing, sought to align his version of the Historia de la donzella Teodor with popular scientific writings of the late medieval period. Some of these writings resembled modern how-to-books, handbooks, or guides. According to William Eamon, their purpose was to provide the reader with "down-to-earth" information that might be exploited for profit or "used for the betterment of humanity" (4). The bulk of this literature consisted of summaries, almanacs, prognostications,

\footnotetext{
${ }^{\circ}$ With reference to gothic type in early Spanish printing, consult Griffin (174-76). Grendler has an excellent discussion of the format and size of popular books printed in Italy.
} 
and compilations of information or "secreta." This class of texts experienced phenomenal success during the late fifteenth and early sixteenth centuries, especially since these texts provided a broad spectrum of readers with access to information previously controlled by the elite specialist (Eamon 94-133).

With respect to the calendar, Hagenbach derives his information from Andrés de Li's Reportorio de los tiempos, a popular compendium containing a wide variety of practical information. ${ }^{7}$ The Reportorio was printed in Burgos in 1493 by Fadrique de Basilea (López Piñero n. 862). The unique witness for this edition survives in an imperfect copy housed in the Hispanic Society of America, New York. A second incunabular edition was printed in Zaragoza in 1495 by Paulus Hurus. A sole witness for this edition is found in the Biblioteca Nacional, Madrid, shelfmark I 2470 [2] (López Piñero n. 864). During the period of 1501-1518, the Reportorio de los tiempos went through seven reprintings, including one printing by Hagenbach's press in $1510{ }^{8}$ The proliferation of Li's text attests to the spread in the Iberian peninsula of scientific writings intended for a popular readership. In Li's text, the reader finds information on the agricultural labors, a guide to zodiacal prognostication, the canons for various astronomical phenomena, and the rules for phlebotomy. ${ }^{9}$ Additionally, the early editions utilized an extensive pictorial program to illustrate the information described in the various sections of the text. Both the Burgos and Zaragoza editions include woodcuts illustrating the labors of the year and the astrological signs. The Zaragoza edition contains a homo signorum (zodiacal man), phlebotomy charts, and illustrations of the phases of the moon. The editions from the early sixteenth century utilized similar pictorial elements for illustrating the scientific information of the text.

The calendar incorporated in the Historia de la donzella Teodor begins on folio 5 recto and continues until folio 6 recto. The calendar

\footnotetext{
'Mettmann (82) and Haro Cortés (Los compendios 43-44) discuss the sources for the calendar. For an edition of the Reportorio, consult Delbrugge.

${ }^{8}$ The seven extant editions of the Reportorio are: Valencia, Cofman, 1501, (Norton n. 1155; López Piñero n. 866); Valencia, Costilla, 1506? (Norton n. 1224; López Piñero n. 867); Seville, Cromberger, 1510, (Norton n. 792; López Piñero n. 868); Toledo, Hagembach. (sic) succ., c. 1510, (Norton n. 1064; López Piñero n. 869); Seville, Cromberger, c. 1514, (Norton n. 847; López Piñero n. 870); Saragossa, [Coci], 1515 (Norton n. 675; López Piñero n. 871); Burgos, [Melgar], 1518, (Norton n. 316; López Piñero n. 872).

${ }^{9}$ For this class of scientific writing, consult the studies by Taavitsainen, Means, Clark, and Varisco.
} 
sections include recommendations for all the months of the year. Throughout this section, the source of Teodor's information is Li's recommendations in the calendar section of the Reportorio, as the following passage clearly demonstrates: ${ }^{10}$

En el mes de ENERO, siendo vieja la luna, deues alimpiar los arboles que perden la foja, e es tiempo despuesto para trasplantar, enxerir, cauar las viñas, los rosales e los gezmines, e raer e entrecauar el alfalfa, e boluer los barbechos e plantar qualquier generacion de ligumes. Deues vsar en este mes los baños e sangrias, e los manjares e potages claros e calientes de su natura, e no deues suffrir que se leuante el estomago de la mesa con sed. Historia de la donzella Teodor: Toledo: Hagenbach, 15001503 , folio 5 recto
Enaqueste mes siendo vieja la luna deues alimpiar los arboles que pierden la foja y es tiempo dispuesto para trasplantar e enxerir para cauar las viñas los rozales e los gezmines: e para raer e entrecavar el alfalfa: e bouer los barbechos: e para plantar qualquiere generacion de legumes. Deues vsar en aqueste mes los baños y las sangrias e los manjares e potajes claros: e calientes de su natura. e no deues suffrir que se leuante el estomago dela mesa con sed. Reportorio de los tiempos. Zaragoza: Paulus Hurus, 1495, sig. D1 verso

Teodor's excursus occurs within the exchange with the first scholar and fits well into the didactic pattern of the quaestio. The information imparts useful knowledge which readers can apply to their everyday lives. Since the descriptions of the months are not included in the extant medieval redactions, this section constitutes a significant expansion of the original text. Hagenbach incorporates this class of writing into his edition of the Historia de la donzella Teodor in order to appeal to readers seeking texts which offered practical information.

The particular calendar appropriated by Hagenbach belongs to a medical-hygienic genre common throughout the late Middle Ages, the regimen sanitatis (Keil). Medical practitioners frequently relied on these hygienic regimina for diagnosing and preventing illnesses. According to García-Ballester ("Changes in the Regimina"), in the Iberian Peninsula the regimina had gained popularity during the fourteenth century and were firmly entrenched in medical practices throughout the peninsula. The materials which Hagenbach has added

\footnotetext{
"All citations from Andrés de Li are taken from the Zaragoza incunable. My tran scription retains the orthography of that incunable and does not add accents or modern punctuation. I expand all abbreviations silently when necessary and use "e" to transcribe the tironian sign. In preparing this study, I have consulted Laura Delbrugge's edition and study of the Reportorio.
} 
to the Historia de la donzella Teodor belong to the popular medical writings which circulated throughout this period.

During the late Middle Ages, information of this type had begun to pass from an elite audience of educators and professionals to a wider public: merchants, craftsmen, and other citizens of late medieval society. With the advent of print, this information became readily accessible in the form of handbooks, manuals and almanacs. Eamon has demonstrated that, in this type of scientific writing, publishers played a crucial role in the selection, arrangement, and distribution of such texts (124-26). The calendar reflects a conscious effort by Hagenbach to align the Historia de la donzella Teodor with the scientific writings which circulated in the late fifteenth century. Hagenbach's activity as a result establishes a new identity for the text. Unlike its medieval redactions, the printed Historia de la donzella Teodor is destined to meet the needs of a readership seeking utilitarian information.

In Hagenbach's redaction, Teodor offers for each of the months a brief description containing hygienic prescriptions and agricultural recommendations. The calendar in the Historia de la donzella Teodor consistently refers to agricultural practices. In the recommendations for September, for example, the following information derived from $\mathrm{Li}$ is given: ${ }^{11}$

Enel mes de setiembre se acostumbran de vendemiar las viñas e deues coger las huuas que quieres para alçar quando la luna es vieja e enla hora mas caliente del dia. En este mes el sembrar los panes es marauilloso: la leche es muy prouechosa. Puedes te sangrar sin peligro, mas las dolencias de los riñones de las nalgas son muy dañosas. (Toledo: Hagenbach, 1500-1503, folio 6 recto)

This kind of agronomical advice echoes agricultural treatises such as the Opus agriculturae of Palladius which circulated in various forms throughout the medieval period. ${ }^{12}$ In the description for June, the His-

${ }^{11} \mathrm{Li}$ provides the source for this passage: "En aqueste mes se acostumbran de vendimiar las viñas e deues coger las huvas que quieres para alçar quando la luna es vieja e enla hora mas caliente del dia. En aqueste mes el sembrar los panes es maravilloso. la leche es muy prouechosa. Puedes te sangrar sin peligro. Mas las dolencias delos riñones e delas nalgas son muy dañosas" (Zaragoza: Paulus Hurus, 1495, sig. E 1 verso).

${ }^{12}$ The agricultural observations for September share some affinities with the descriptions in the Libro de Paladio, the Aragonese translation of Palladius: "En los 
toria de la donzella Teodor includes specific mention of Palladius: "E como escriue Palladio: si en aqueste mes siegas tu trigo en la luna vieja se coseruara mas tiempo que no si se siega enla nueua" (folio 5 verso). ${ }^{13}$ It is not unusual for regimina to discuss issues related to agriculture since some of this information was used in conjunction with discussions of food and dietary restrictions. By means of the regimina, late medieval medical practitioners sought to regulate human life in order to avoid illness and maintain health (García, "Dietetic ..." 24-25).

In addition to the calendar, Hagenbach incorporates information concerning human sexuality. As with the calendar, Hagenbach weaves this discussion into the quaestio format of the Historia de la donzella Teodor without disrupting the original story. The discussion, missing from extant pre-1400 redactions of the Historia de la donzella Teodor, reflects the dominant medical discourse of late medieval Castile (Haro Cortés, "Erotismo y arte .. ." 125; Lacarra 28-35). The first printed edition of the Historia de la donzella Teodor reflects the practices of a publisher who consciously adapts scientific writings in order to fashion a text destined for consumption by a general, nonspecialist public.

The process of adaptation emerges quite concretely in the sections dealing with sexual matters. In the pre-1400 redactions of the Historia de la donzella Teodor, the first reference to human sexuality occurs during Teodor's exchange with the second "sabio" from the court. The quaestio provides a clear example of Hagenbach's negotiation of sources. Teodor must reply to the question: "Qual es la cosa que mas envegesce al hombre antes de tiempo" (Toledo: Hagenbach, 1500-1503, folio 7 recto). In the redaction of the Historia de la donzella Teodor found in Escorial Ms. h-III-6, the response to the quaestio focuses on ethical and theological issues:

dixo la donzella la debda e la porydat descobierta \& dormir con muger vieja que es pecado mortal. (folio 120r)

While the Escorial redaction places the erotic within the context of religious discourse, Hagenbach's edition moves the text toward the discursive practices of late medieval scientific culture. In the Toledo edition, Teodor replies in two stages. Her initial response to the "sa-

\footnotetext{
lugares calientes \& çerca dela mar acostumbran de fazer vendimja en aqueste mes et en los lugares frias aparejan vendimjas" (189) and "Los rrazimos o vuas que querras saluar es menester que sean cogidas fuert gallardament que non sean golpeadas" (192).

${ }^{13}$ The reference to Palladius also occurs in the early editions of Li. See Burgos: Fadrique de Basilea, 1493, sig. D6 verso.
} 
bio's" question echoes the Escorial version of the text: "El dormir mucho con mugeres" (Toledo: Hagenbach, 1500-1503, folio 7 recto). Teodor then continues with an elaboration which frames the answer within the discourse of late medieval science:

Ca dize Aristotle, fablando de los luxuriosos, que toda su obra era ponçoñosa, porque los hombres dauan la mejor sangre de su cuerpo, e las mugeres dauan la peor que tenian. (Toledo: Hagenbach, 1500-1503, folio 7 recto)

Teodor's answer goes beyond the simple question-reply pattern and provides an explanation supported by an authority, in this case Aristotle. The reply, in fact, rehearses a commonplace of medieval scientific thinking concerning the differences between the sexes. Hagenbach's handling of this information reflects an awareness of contemporary discussions of this issue. In the scientific writings of this period, medieval theorists believed that intercourse was harder on men than on women, because men emitted more of their vital heat than women did (Cadden 175-77). The commentary to the PseudoAlbertus Magnus's De secretis mulierum, an influential medical text of the period, illustrates the concepts to which Teodor alludes:

The more women have sexual intercourse, the stronger they become, because they are made hot by the motion that the man makes during coitus. Further male sperm is hot because it is of the same nature as air and when it is received by the woman it warms her entire body, so women are strengthened by this heat. On the other hand, men who have sex frequently are weakened by this act because they become exceedingly dried out. (PseudoAlbertus Magnus 127)

According to Helen Rodnite Lemay (in Pseudo-Albertus 32-49), echoes of this concept appear in numerous natural science treatises and medical manuals from the late medieval period. Although Hagenbach treats this material in an abbreviated fashion, the handling of the topic is consistent with his practice of incorporating scientific discourse into the Historia de la donzella Teodor.

The reference to Aristotle in the quaestio from the Historia de la donzella Teodor strengthens the text's ties with contemporary scientific writings. Aristotle's treatises were seen as the starting point for any discussion of human sexuality (Cadden 117-30). Medieval scientific writings frequently cited Aristotle's statement in On the Generation of Animals that "The male provides the 'form' and the 'principle of the movement,' the female provides the body, in other words, the material" (109) as the basis for the censure of women 
because of their physical nature. Hagenbach most likely knew of this through contact with sources readily available to readers from this period. An example of a contemporary treatment of this topic can be found in Johannes de Ketham's Fasciculus medicinae: Compendio de la salud humana (Zaragoza: Paulus Hurus, 1494), a reference book intended to provide medical information for non-professionals. The text contains a series of quaestiones in which readers receive information concerning various medical topics. Ketham's text utilizes the question/answer format to instruct the readers concerning these medical issues and presents the information for use by non-specialist readers. Michael Solomon has characterized the Compendio as a type of "Viaticum," a portable, readily accessible handbook for travelers.

A question concerning the dangers of intercourse also occurs in the Compendio and suggests a possible intertext for the Historia de la donzella Teodor. Ketham begins with the quaestio "¿Por qué el desordenado ayuntamiento y muy continuo es venenoso y dañoso?" (119). The response offers the explanation: "Porque, como escribe Aristóteles en el libro de la generación de los animales, la lujuria no es sino una expulsión de la humedad, la cual consume el cerebro y trae consigo algunas fiebres agudas" (Ketham 119-20). Ketham's quaestio gives a context for the type of discourse utilized in the Historia de la donzella Teodor. The description of the effects of "lujuria" provides insight into the ways in which writers of scientific manuals structured their discussion. Hagenbach is appropriating this vocabulary and the discursive patterns present in late medieval scientific writings.

By bringing this type of discourse into the Historia de la donzella Teodor, Hagenbach adapts information already in circulation in printed form and makes it accessible to a non-specialist audience. The Compendio, incidentally, was published in Zaragoza by Hurus, the publisher of the Reportorio de los tiempos. The discussion of human sexuality in the Historia de la donzella Teodor not only reflects an awareness of the scientific literature of the late fifteenth century, but also attests to Hagenbach's function as reader/compiler of scientific literature.

Hagenbach's adaptation of the Historia de la donzella Teodor produces a text which shares in the discursive practices of late medieval scientific writing. A second example illustrates the extent to which Hagenbach is consistently weaving that scientific discourse into the text. The "sabio" asks Teodor to comment on the proper techniques 
for sexual arousal. The version printed by Hagenbach approaches the topic with an extensive description of these techniques:

Señor maestro, sabed que si la muger fuere tardia en su voluntad, deue el hombre que dormiere con ella ser sabio, como dicho tengo, e conoscer su complexion; e deuese detardar con ella, burlandose con ella e haziendole de la tetas e apretandogelas, e a vezes ponerle la mano en el papagayo, e otras vezes tenerla encima de si, e a vezes de baxo. $\mathrm{E}$ haga por tal manera que las voluntades de los dos vengan a vn tiempo. E si por ventura, la muger veniere a complir su voluntad mas ayna que el hombre, deue el con discrecion entenderla e jugar vn rato con ella, porque la haga complir otra vez, e vengan juntas las voluntades de amos, como de suso dixe. E haziendolo desta manera, amarle ha mucho la muger. (Toledo: Hagenbach, 1500-1503, folios 7 verso- 8 recto)

This enumeration of techniques, missing from the manuscript redactions of the Historia de la donzella Teodor, ${ }^{14}$ reveals the extent to which praxis has become a dominant force within the text. The demure Teodor describes a process for erotic stimulation. Her knowledge provides an explicit guide to the pleasure, not to its propriety or moral value (Lacarra 29-35).

A closer examination of the passage reveals that the Historia de la donzella Teodor is echoing the observations of other medical writers from the Middle Ages. The Historia de la donzella Teodor testifies to the accretion of various layers of scientific discourse. From the eleventh century on, Arab theorists, such as Avicenna and At-Tîfâshî, had described these techniques in their writings (Jacquart 125-38)..$^{15}$

\footnotetext{
${ }^{14}$ This quaestio appears in a somewhat abbreviated form in the manuscript redactions of the Historia de la donzella Teodor. In the Escorial manuscript, the first "sabio" requests infomation about sleeping with women ("yazer con las mugeres" Escorial, Ms. h-III-6, folio 120 verso). In that redaction, Teodor offers a succinct answer: "todo yazer con muger es dolença quando ayas de yazer conella podra ser que sea

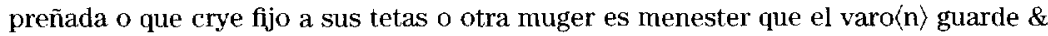
sea sabidor" (Escorial, Ms. h-III-6, folio 120 verso).

${ }^{15}$ Avicenna in the Canon advises: "Men should take their time over playing with women who do not have a poor complexion. They should caress their breast and pubis, and enfold their partners in their arms without really performing the act. And when their desire is fully roused, they should unite with the woman, rubbing the area between the anus and the vulva. For this is the seat of pleasure." (Canon, bk III, fen 20, tr. 1, ch. 38, cited in Jacquart 131). At-Tîfâshî recommends a similar technique: "The woman is drawn to sexual commerce, when one plays with her breast, and, especially when she is older, do not deprive her of this pleasure." (On What is Useful to Women and Men in the Practice of Sexual Intercourse, on What is Favorable, and What is Harm$f u l$, cited in Jacquart 125).
} 
Similar descriptions appear in other medical texts from the period. John of Gaddesden in the Rosa Anglica, a fourteenth-century medical handbook first available in printed form in 1492, recommends the following procedures for stimulating pleasure: "Et debet tangere mulierem cum manu contra muliebria et mamilias, et osculari eam. Deinde cognoscere eam" (And he should touch the woman with his hand on her genitals and breasts, and kiss her; then know her)" (Cited and translated by Cadden 248).

One further analogue comes from the Lilio of Bernardo de Gordonio, a standard medical reference book first composed during the fourteenth century. The Castilian translation of the Lilium, published in Sevilla by Meynardo Ungut and Stanislao Polono in 1495, confirms the availability of this type of information during the period prior to Hagenbach's publication of the Historia de la donzella Teodor. In a section entitled "De qué manera se ha de acostar el varón con la mujer," Bernardo offers a series of recommendations analogous to the ones given by Teodor:

Despues dela media noche e ante del dia, el varon deue despertar ala fembra, fablando, besando, abraçando e tocando las tetas e el pendejo e el periteneon; todo esto se hace para avivar el deseo en la mujer y para que las dos simientes concurran juntamente porque las mujeres expulsan la esperma más tarde.

(1501)

The text of Bernardo de Gordonio is particularly significant since it attests to the circulation of similar sexological information in the vernacular in Castile prior to the compilation of Hagenbach's Historia de la donzella Teodor. The Lilio was the first major medical treatise translated into Castilian (Bernardo de Gordonio 31). The appropriation of contemporary scientific materials is consistent with Hagenbach's pattern of compilation, and it is not beyond the realm of possibility that Hagenbach was familiar with the Lilio.

Hagenbach turned to vernacular scientific writings in order to expand the scope of the Historia de la donzella Teodor. The discussion of human sexuality mirrors contemporary discussions of the topic and offers the readers the opportunity to acquire knowledge and practical techniques. Similarly, the hygienic prescriptions and agricultural advice of the calendar provide scientific information which will be of practical use to lay and learned readers alike. The communication of that scientific information constitutes a significant addition to the textual identity of the Historia de la 
donzella Teodor. The additions made by Hagenbach conform to the practices adopted by various early publishers seeking to address the shifting demands of the market and of the readership. As a result, Hagenbach was able to redefine the scope and nature of the original Historia de la donzella Teodor and create a distinctive textual identity which reflects the cultural dynamics of a society entering the age of print. ${ }^{16}$

\section{WORKS CITED}

Aristotle. On the Generation of Animals. Trans. A. L. Peck. Cambridge, MA: Harvard UP, 1979.

Baranda, Nieves and Víctor Infantes. "Post Mettmann. Variantes textuales y transmisión editorial de la Historia de la donzella Teodor." La Corónica 22 (1993-1994): 61-88.

Bernardo de Gordonio. Lilio de Medicina. Ed. Brian Dutton y María Nieves Sánchez. 2 vols. Madrid: Arco, 1993.

Bizzarri, Hugo Oscar, ed. Diálogo de Epicteto y el emperador Adriano (Derivaciones de un texto escolar en el siglo XIII). Frankfurt am Main: Vervuert, 1995.

Bocados de oro. Ed. Mechthild Crombach. Bonn: Romanisches Seminar der Universität Bonn, 1971.

Brown, Cynthia. Poets, Patrons, and Printers: Crisis of Authority in Late Medieval France. Ithaca: Cornell UP, 1995.

Cadden, Joan. Meanings of Sex Difference in the Middle Ages: Medicine, Science, and Culture. Cambridge: Cambridge UP, 1993.

${ }^{16}$ A preliminary version of this paper was read at the Kentucky Foreign Language Conference (Lexington, 1995) in a section organized by Professor John E. Keller. A visit to the Biblioteca Nacional, Madrid, in October 1995 was generously subsidized by the University of Kansas Office of Study Abroad. This study owes much to Donna Rogers's generosity and collegiality. Laura Delbrugge provided valuable insights on the workings of medieval calendar texts. I am grateful to José Ballesteros and Andrea Baldomir for their insights into the cultural dynamics of these texts. I owe special thanks to Ms. Susan Rosenstein, Curator at The Hispanic Society of America, for her assistance in obtaining access to the Li's Reportorio. Cynthia L. Barnett kindly read portions of this paper and saved me from numerous mistakes. For those errors which remain, I alone am responsible. 
Chambers, Marlene. "Early Printing and Book Illustrations in Spain." The Literary Chronicle 39 (1973): 3-17.

Chartier, Roger. The Order of Books: Readers, Authors, and Libraries in Europe between the Fourteenth and Eighteenth Centuries. Stanford: Stanford UP, 1994.

Clark, Charles West. "The Zodiac Man in Medieval Medical Astrology." Diss. University of Colorado, 1979.

Cross, James E. and Thomas D. Hill. The Prose "Solomon and Saturn" and "Adrian and Ritheus." Toronto: Toronto UP, 1982.

Delbrugge, Laura. "A Critical Edition of Andrés de Li's Reportorio de los tiempos (1495)." Diss. The Pennsylvania State University, 1996.

Deyermond, Alan D. La Edad Media. Trans. Luis Alonso López. Historia de la Literatura Española 1. Barcelona: Ariel, 1980.

Eamon, William. Science and the Secrets of Nature: Books of Secrets in Medieval and Early Modern Culture. Princeton: Princeton UP, 1994.

García-Ballester, Luis. "Changes in the Regimina sanitatis: The Role of the Jewish Physicians." Health, Disease and Healing in Medieval Culture. Ed. Sheila Campbell, Bert Hall, and David Klausner. New York: St. Martin's Press, 1992. 119-31.

_. . "Dietetic and Pharmacological Therapy: A Dilemma among Fourteenth-Century Jewish Practitioners in the Montpellier Area." Clio Medica 22 (1991): 23-37.

Gerresch, C. "Un récit des Mille et une Nuits: Tawaddud." Bulletin de l'Institut Fondamental D'Afrique Noire. Série B, Sciences Humaines 35 (1973): $57-175$.

Goldschmidt, Ernest. Medieval Texts and their First Appearance in Print. London: Bibliographical Society, 1943.

Grendler, Paul F. "Form and Function in Italian Renaissance Popular Books." Renaissance Quarterly 46 (1993): 451-85.

Griffin, Clive. The Crombergers of Seville. The History of a Printing and Merchant Dynasty. Oxford: Clarendon, 1988.

Haro Cortés, Marta. "Erotismo y arte en el discurso médico de la Historia de la donzella Teodor." Revista de Literatura Medieval 5 (1993): $113-25$.

—. Los compendios de castigos del siglo XIII: técnicas narrativas y contenido ético. Valencia: U de València, 1995.

Historia de la donzella Teodor. Toledo: Pedro Hagenbach, 15001503. 
Jacquart, Danielle and Claude Thomasset. Sexuality and Medicine in the Middle Ages. Trans. Matthew Adamson. Princeton: Princeton UP, 1988.

Keil, Gundolf. "Das Regimen duodecium mensium der 'Düdescher Arstedie' und das Regimen sanitatis Coppermici." Niederdeutsches Jahrbuch 81 (1958): 33-48.

Ketham, Johannes de. Compendio de la salud humana. Ed. María Teresa Herrera. Madrid: Arco, 1990.

Lacarra, María Eugenia. "Parámetros de la representación de la sexualidad femenina en la literatura medieval castellana." La mujer en la literatura hispánica de la Edad Media y el Siglo de Oro. Ed. Rina Walthaus. Amsterdam: Rodopi, 1993. 23-43.

Lawn, Brian. The Salermitan Questions. An Introduction to the History of Medieval and Renaissance Problem Literature. Oxford: Clarendon, 1963.

Lawrance, J. N. H. "The Spread of Lay Literacy in Late Medieval Castile." BHS 62 (1985): 79-94.

Li, Andrés de. Reportorio de los tiempos. Burgos: Fadrique de Basilea, 21 May 1493.

- - Reportorio de los tiempos. Zaragoza: Paulus Hurus, 10 June 1495.

Libro de Paladio-Obra de agricultura. Traducida y comentada en 1385 por Ferrer Sayol. Ed. Thomas Capuano. Madison: Hispanic Seminary, 1990.

López Piñero, José M. et al. Los impresos científicos españoles de los siglos xv $y$ xvi. Cuadernos Valencianos de Historia de la Medicina y de la Ciencia. Serie C, Repertorios Bio-bibliográficos, xxIII, XxVI. 3 vols. Valencia: Cátedra de Historia de la Medicina, 1981.

Means, Laurel. Medieval Lunar Astrology: A Collection of Representative Middle English Texts. Lewiston: The Edwin Mellen $\mathrm{P}, 1993$.

Mettmann, Walter, ed. La Historia de la Donzella Teodor: Ein spanisches Volksbuch arabischen Ursprungs Untersuchungen und kritische Ausgabe der ältesten bekannten Fassungen. Akademie der Wissenschaft und der Literatur, Abhandlungen der geistesund sozialwissenschaftlichen Klasse, Jahrgang 1962, nr. 3. Wiesbaden: Verlag der Akademie der Wissenschaft und der Literatur in Mainz, 1962.

Morrás, María. " 'Tractado de Segundo filósofo que fue en Athenas': Otro manuscrito inédito." BHS 67 (1990): 279-84. 
Nalle, Sara T. "Literacy and Culture in Early Modern Castile." Past and Present 125 (1989): 65-96.

Norton, F. J. A Descriptive Catalogue of Printing in Spain and Portugal 1501-1520. Cambridge: Cambridge UP, 1978.

Parker, Margaret R. The Story of A Story Across Cultures: The Case of the Doncella Teodor. London: Tamesis, 1996.

Pseudo-Albertus Magnus. Women's Secrets: A Translation of Pseudo-Albertus Magnus's De Secretis Mulierum with Commentaries. Trans. Helen Rodnite Lemay. Albany: State $U$ of New York P, 1992.

Rivera, Isidro J. "The Historia de la linda Melosina and the Construction of Romance in Late Medieval Castile." MLN 112 (1997): 131-46.

Rogers, Donna M. Transcription of Escorial Ms. h-III-6, "Capitulo que fabla delos enxemplos \& castigos de teodor la donzella." Typescript, unpublished edition, 1995.

Schmitt, Charles. "Aristotle among the Physicians." The Medical Renaissance of the Sixteenth Century. Ed. A. Wear, R. K. French, \& I. M. Lonie. Cambridge: Cambridge UP, 1985. 1-15.

Severin, Dorothy Sherman. “'El ynfante Epitus': The Earliest Complete Castilian Version of the Dialogue of 'Epictetus and the Emperor Hadrian'." BHS 62 (1985): 25-30.

Simón Díaz, José. "La literatura medieval castellana y sus ediciones españolas de 1501 a 1560." El libro antiguo español: actas del primer Coloquio Internacional (Madrid, 18 al 20 de diciembre de 1986). Ed. María Luisa López-Vidriero and Pedro M. Cátedra. Salamanca: U de Salamanca, 1988. 371-96.

Solomon, Michael. "Portable Medical Handbook". Message posted on MEDIBER: Medieval Iberia Mailing List. 12 May 1995.

Solterer, Helen. The Master and Minerva: Disputing Women in French Medieval Culture. Berkeley: U of California, 1995.

Suchier, Walter. L'Enfant sage (Das Gespräch des Kaisers Hadrian mit dem klugen Kinde Epitus). Gesellschaft für romanische Literatur 24. Dresden: Max Niemeyer, 1910.

- Das mittellateinische Gespräch Adrian und Epictetus nebst verwandten Texten (Joca Monachorum). Tübingen: Niemeyer, 1955.

Taavitsainen, Irma. Middle English Lunaries: A Study of Genre. Helsinki: Société Néophilologique, 1988.

Taylor, Barry. "Old Spanish Wisdom Texts: Some Relationships." $L a$ Corónica 14 (1985): 71-85. 
Varisco, Daniel Martin. Medieval Agriculture and Islamic Science: The Almanac of a Yemini Sultan. Seattle: $\mathrm{U}$ of Washington P, 1994.

Whinnom, Keith. "The Problem of the 'Best-Seller' in Spanish GoldenAge Literature." Medieval and Renaissance Spanish Literature: Selected Essays. Ed. Alan Deyermond, W. F. Hunter, and Joseph T. Snow. Exeter: U of Exeter P, 1994. 159-75. 